\title{
The Kaaba of New York
}

Simon O’Meara

This essay concerns the Internet-based outcry that occurred on October II, 2006, when the U.S.-based Middle East Media Research Institute (MEMRI) reported that an Islamist website had, the day before, alleged that Apple Inc.'s under-construction flagship storefront in New York resembled the Kaaba of Mecca and was thus intended to provoke Muslims. The report read as follows:

On October Io, 2006, an Islamist website posted a message alerting Muslims to what it claims is a new insult to Islam. According to the message, the cube-shaped building which is being constructed in New York City, on Fifth Avenue between $58^{\text {th }}$ and $59^{\text {th }}$ Streets in midtown Manhattan, is clearly meant to provoke Muslims. The fact that the building resembles the Ka' ba [...], is called »Apple Mecca, « is intended to be open 24 hours a day like the Ka'ba, and moreover, contains bars selling alcoholic beverages, constitutes a blatant insult to Islam. The message urges Muslims to spread this alert, in hope that »Muslims will be able to stop the project. $\aleph^{2}$

This report triggered the virtual storm in a teacup. The details of this surprisingly long-lived but, as will be explained later, mostly muted outcry, are not of interest in this essay. What matters is that, for some people, the Apple storefront constituted an offense, or worse, an insult to Islam, despite the fact that Apple Inc. was reported in newspapers to have issued a statement saying, »[The storefront] is not an attempt to resemble the Kaaba. « ${ }^{3}$ The question that follows from this reaction is: how exactly did the storefront achieve this offense or insult? The fact that it was allegedly intended to be used as a bar, as related in the MEMRI report, is obviously one reason; but this reason would have had no purchase with 


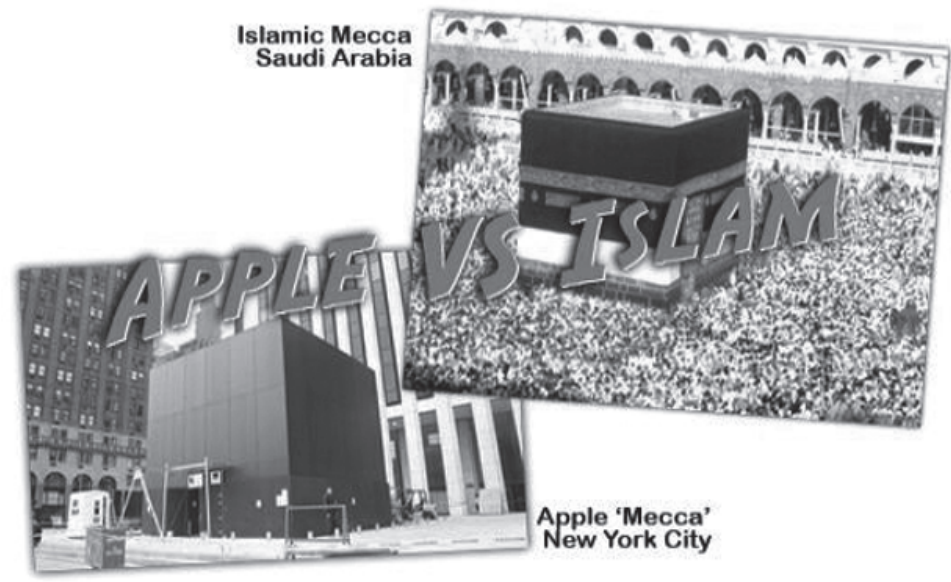

[FIG. 1]

Internet meme, ,Apple vs. Islam

readers of the report were it not for the fact that, as also related in the report, the under-construction and therefore black-clad structure bore a passing resemblance the Kaaba of Mecca. This resemblance was sufficiently evident for all to see, giving rise to the Internet meme associated with the outcry (Fig. I).

The supposition that the underlying reason for the outcry was the perceived visual resemblance between the storefront and the Kaaba must, however, be suspect; for during the lifetime of the Prophet Muhammad a number of cultic buildings in Arabia are said to have existed that either somehow resembled or precisely imitated, and thus rivaled, the Kaaba. At least four such buildings are known from the early Islamic historiography, all of them referred to as »kaabas, «but by no means did all of them incite the early followers of the Prophet to retaliatory action. ${ }^{4}$ Rather, only one was ordered by the Prophet to be attacked and destroyed; 
although the destruction of one other, not included among these four because destroyed immediately prior to the Prophet's time, is additionally alleged to have met with his approval. ${ }^{6}$ After the lifetime of the Prophet, in the medieval Islamic period, Muslim geographers and historians report the existence of additional copies of the Kaaba.7 For example, in the ninth century, the Abbasid Caliph, al-Mutașim (r. 833-42), allegedly built a replica of the Kaaba in the palatine city of Samarra, Iraq, adding to it a pavement for its ritual circumambulation, similar to the pavement (mațâf) around the Kaaba in Mecca. ${ }^{8}$ In the tenth century, a mosque with the same dimensions as the Kaaba is said to have been built in Cairo (Fusțât). ${ }^{9}$ Later, in the $14^{\text {th }}$ century, another similarly proportioned mosque is reported as standing opposite the church in Erzurum, in present-day Turkey; it was allegedly known as the Kaaba Model. ${ }^{10}$ Lastly in this brief overview, in the $13^{\text {th }}$ century, the Iraqi luminary al-Harawi (d. 1215 ) is said to have been buried in a mausoleum that was shaped like the Kaaba. ${ }^{\text {II }}$

Given that the Prophet is alleged to have suffered the existence of three of the four aforementioned rival kaabas, and that Kaaba copies continued to be built after his death, the offense to Islam that the Kaaba of New York represented for some people cannot be satisfactorily attributed to the perception that it was a Kaaba copy. Indeed, Kaaba copies have continued to be built without issue long after the medieval period, including, specifically, during the last fifty years. ${ }^{\mathrm{I2}}$ The most notable of these recent copies is perhaps the artist Gregor Schneider's Cube Hamburg 2007 that was intended first for the 2005 Venice Biennale and later for the 2006 Berlin Biennale. On both occasions, the Cube's display was banned not by self-identifying Muslims, but by officials of the two exhibitions, fearing it might cause offense to Islam. ${ }^{13}$ 
In this last instance, in contrast to the »Kaaba of New York, « the fact that the Cube bore an intentional, albeit reductive resemblance to the Kaaba, and originally had even been planned to be an exact copy of the Kaaba, was indeed the underlying reason for the censorship. ${ }^{\mathrm{I}}$ However, the difference between this instance and that of the »Kaaba of New York« is that the individuals who censored the Cube were the over-cautious but ignorant exhibition officials; not self-identifying Muslims. These officials correctly perceived the Cube as a Kaaba copy, but incorrectly supposed this perception might prove offensive to others. No Muslim is on record as offended. ${ }^{\text {I5 }}$

With regard to the »Kaaba of New York, « the example of Schneider's Cube proves the necessity of a perception in the minds of the offended individuals of a visual resemblance between the under-construction storefront and the Kaaba. The offended must see the storefront as a Kaaba copy. Additionally, the example proves the volatile power and near-inevitability of such a perception. Simultaneously, the example exposes the inability of this perception to account for the resulting offense.

If the perception of Apple's storefront as a Kaaba copy does not account for the outcry the building provoked, what does? As will be argued below, one explanation is that the storefront was seen as out of place. ${ }^{16}$

\section{Out of place}

In the dictum made famous by the social anthropologist, Mary Douglas, dirt is matter out of place. As Douglas exemplifies this dictum: 
Shoes are not dirty in themselves, but it is dirty to place them on the dining-table; food is not dirty in itself, but it is dirty to leave cooking utensils in the bedroom, or food bespattered on clothing; similarly, bathroom equipment in the drawing room; clothing lying on chairs; out-door things in-doors; upstairs things downstairs; under-clothing appearing where overclothing should be, and so on. ${ }^{17}$

As Douglas glosses this dictum:

Where there is dirt there is system. Dirt is the by-product of a systematic ordering and classification of matter, in so far as ordering involves rejecting inappropriate elements. This idea of dirt takes us straight into the field of symbolism [....] $[\mathrm{P}]$ ollution behaviour is the reaction which condemns any object or idea likely to confuse or contradict cherished classifications. ${ }^{18}$

If we see in Douglas's discussion of matter versus dirt an analogy with the foregoing discussion of the »Kaaba of New York«, whereby there is nothing inherently wrong with a building resembling or imitating the Kaaba of Mecca (»matter«), but there is offense and even insult to be had when this resemblance falls foul (»dirt«) of the Muslim beholders' symbolic system - their inherited system of ordering and classifying the world - then we begin to grasp the relevance of the dictum for this essay. To grasp its relevance fully, however, the term »place« must not be understood in some local, site-specific way; for then the dictum would imply that the offense or insult arising from the »Kaaba of New York« was due to the building's location, downtown Manhattan, and that if it were 

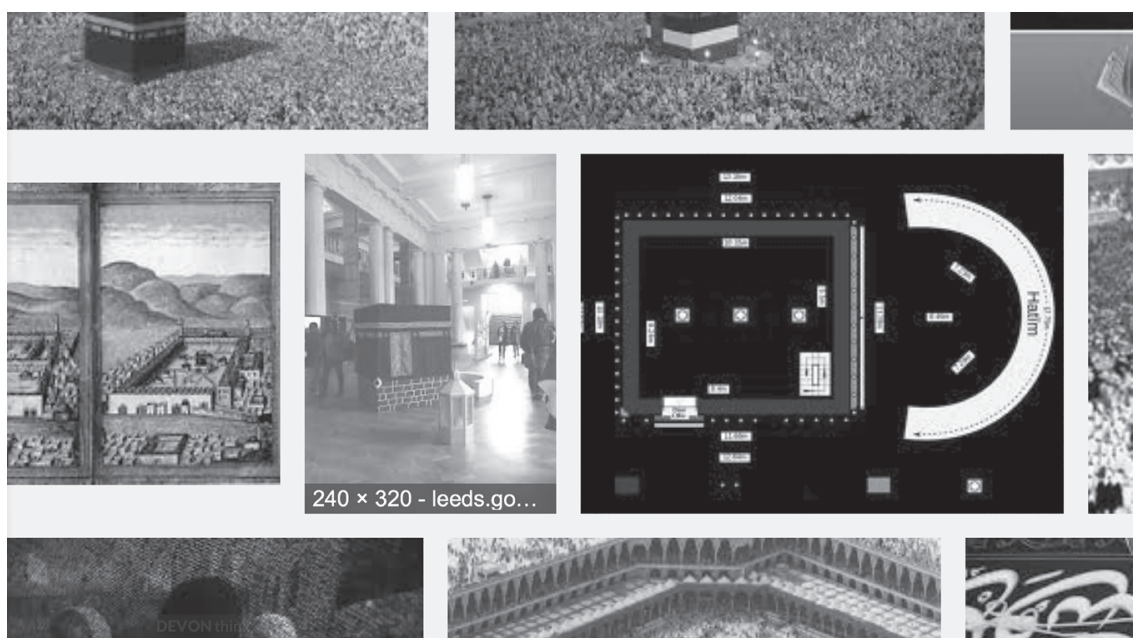

[FIG. 2]

Screenshot of the Google search window following a search of the combined words »Kaaba« and »copy«

relocated to an open space, a desert say, the offense or insult would disappear. Such a conclusion would be wrong; and the proof of that lies in a discussion of the »Kaaba of Leeds.»

In a Google image-based search of the combined words »Kaaba« and »copy, « one of the sites that results is a photograph of Leeds University's main hall, the Parkinson Court, in the middle of which sits a three-dimensional, reduced-scale copy of the Kaaba of Mecca. A screenshot of the Google search window showing this photograph amid other Kaaba images found by the search engine is reproduced below (Fig. 2). 
In this photograph, people can be seen milling past the Kaaba replica with no evidence of unease or outcry; in fact they barely seem to notice it, even though it is there for educational purposes, as the website linked to the photograph explains. ${ }^{19}$ But this disregard is not what is important for present purposes. ${ }^{20}$ What matters is the setting of this replica, the place in which it is located, namely, the art deco grandeur of the Parkinson Court, part of the Grade II listed Parkinson Building, built between 1936 and 1951. This setting is not too different from that of the »Kaaba of New York.« Both settings are, after all, expressive of ideologies and economies that have no obvious basis in Islam and its omphalos, the Kaaba of Mecca. One might refer to both as modern Western and non-Islamic. This similarity between the two settings notwithstanding, only the »Kaaba of New York « prompted outcry. ${ }^{21}$ The geographic location - the location's specific architectural setting and space - cannot, therefore, be what is meant by the term »place« in the dictum that dirt is matter out of place. How, then, should the term be understood? The following answer to this question invokes the thought of the historian of religion, Jonathan Z. Smith, the philosopher, Martin Heidegger, and the architectural theorist, Mark Wigley.

According to Smith, the process by which an incipient society develops a competing, reproducible, and expandable symbolic order depends on its vision of its place. He does not say »founding place, « but the context implies that. He writes:

The question of the character of the place on which one stands is the fundamental symbolic and social question. Once an individual or culture 
has expressed its vision of its place, a whole language of symbols and social structures will follow. ${ }^{22}$

Smith's words can be made to resonate further when paired with Wigley's reading of Heidegger's well-known discussion of »a Greek temple« in the essay, The Origin of the Work of Art. Of this temple, Heidegger writes:

The temple, in its standing there, first gives to things their look and to men their outlook on themselves. This view remains open as long as the work is a work, as long as the god has not fled from it. ${ }^{23}$

Punning on the words sight and site, Wigley reads Heidegger to mean:

[The temple] is not simply looked at by an eye, aesthetic or otherwise. Rather, it constructs the eye. [The temple] produces its site. ${ }^{24}$

On the basis of Wigley's reading of Heidegger, Jonathan Z. Smith's observation about the generative function of (founding) places leads to the conclusion that the term "place, « in the dictum made famous by Mary Douglas, means outlook, one informed by and tied to a specific symbolic order. The symbolic order generated by the place of the Kaaba of Mecca means that Muslims have an outlook on the world different from that, say, of the ancient Greeks. This outlook of theirs is always present, regardless of their current, individual, particular geographical coordinates; for example, their place of work, their city of study, and so forth. 
To substantiate this last assertion requires showing the basic contours of the outlook on the world that the foregoing paragraph claims is generated by the place of the Kaaba. One cannot, of course, scientifically prove an assertion that claims validity for a numberless group of people; but one can produce evidence to show empirically that such an outlook exists, and has done so for centuries.

To do this, it is insufficient to tie the alleged outlook on the world to Islamic narratives relating the creation of the world; for example, early historiographic traditions relating how the world unfolded from the Kaaba. Instances of such traditions include: »Forty years before Allah created the heavens and earth the Kaaba was a dry spot floating on the water, and from it the world has been spread out; $\ll^{25}$ and ॠThe [Kaaba] was created two thousand years before the earth, and from it the earth was spread forth. $\ll^{26}$ Important though these world-founding narratives are, they do not speak of an outlook, a view, generated by the Kaaba; rather, they speak of a world generated from the Kaaba, which is not quite the same thing. Additionally, a question remains regarding these narratives' reach in the societies where they were recorded, as well as their subsequent longevity in these societies: to what extent are they representative of more than the literary elites? Islamic material culture evidence has a better claim to being representative of more than just the literate minority, if only because material culture commonly involves the marshaling of more forces, more people, including artisans, for its production. It more obviously bespeaks a collectivity. Accordingly, Islamic material culture evidence will be referred to in the following attempt to draw the basic contours of the outlook on the world I submit is generated by the place of the Kaaba. 


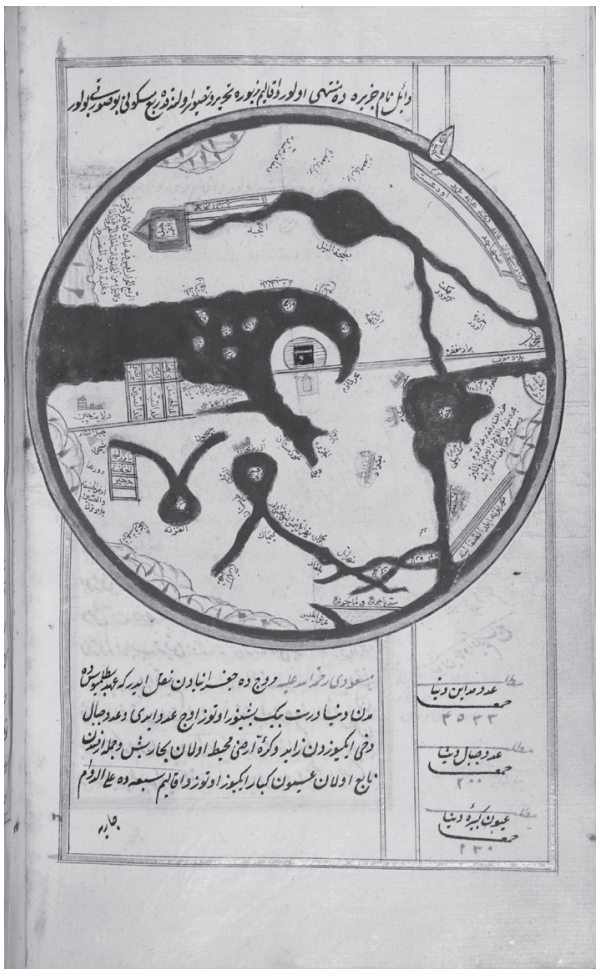

[FIG. 3]

Mappamundi with a representation of the Kaaba at the center, pasted into a copy of an anonymous $16^{\text {th }}$-century Ottoman work, History of the West Indies, dated 1650. Gouache, gold, and ink on paper; $13.6 \times 23.2 \mathrm{~cm}$, Leiden University Library. MS Leiden, Or. 12.365, fol. $90 \mathrm{~b}$

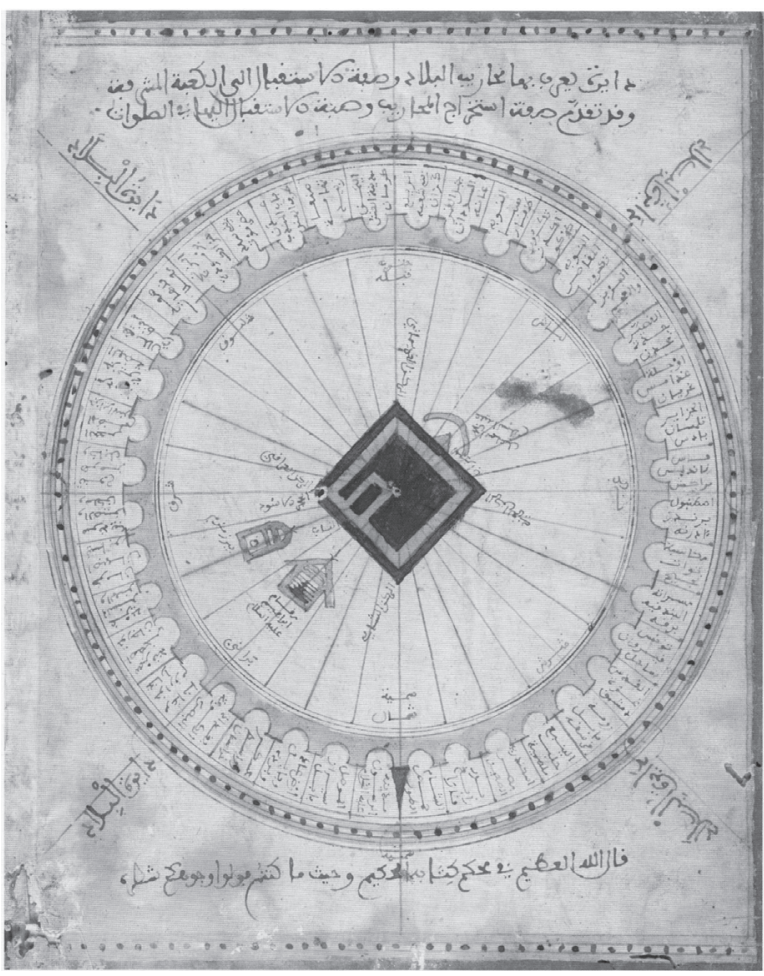

[FIG. 4]

'Ali al-Sharafi al-Safaqusi's nautical diagram of 1572 , showing a 40 -sector division of the Kaaba for determining the qibla direction, superimposed upon a 32 -division wind rose. Gouache and ink on paper; $20.7 \times 26.8 \mathrm{~cm}$, The Bodleian Libraries, The University of Oxford. MS. Marsh 294 , fol. $4 \mathrm{~V}$ 


\section{The outlook from the Kaaba}

As is well known, the Islamic world is oriented toward the Kaaba, with mosques and even some cities in their entirety directed toward it (Fig. 3).

This direction is known as the qibla, and Muslim scientists, cartographers, and others have for centuries conventionally mapped cities and other localities in the Islamic oikumene in accordance with this qibla direction: the direction from the locality toward the Kaaba. ${ }^{27}$ In a reversal of this convention, however, the mid-1 $6^{\text {th }}$ century Tunisian nautical cartographer, 'Ali al-Sharafi al-Safaqusi, plotted the locations using the counter-qibla direction: the direction from the Kaaba toward the cities and localities (Fig. 4). In this scheme, it is as if the Kaaba were looking out toward these locations, assigning their bearings; which is to say, the outlook from the Kaaba is generative. It organizes the world.

Although a quick glance at al-Sharafi al-Safaqusi's scheme might not readily reveal the use of the counter-qibla for its construction, that is what has been used for it; and as Petra Schmidl and Mónica Herrera-Casais have shown, this scheme is not the first instance of it, for it can be dated to at least the late ninth century. ${ }^{28}$ Indeed, as these two academics go on to say:

The scheme $[. .$.$] based on counter-qibla directions from the perspective$ of the Ka'ba looking out to other regions [...] surely derives from the earliest geographical divisions of the world around the Ka ba that were implied in the naming of the corners of the building. ${ }^{29}$ 
With the phrase, »the naming of the corners of the building, «Schmidl and HerreraCasais are referring to the fact that some scholars think the corners of the Kaaba took their names from the geographic regions that the corners abut; $3^{30}$ hence, for example, the »Yamani« corner is the name of the corner abutting Yemen, and the »Shami« corner is the name of the corner abutting Syria (al-Sham). In a traditional account of the corners' names, however, these same two corners, "Yamani« and »Shami, « are said to have given their names to the geographical regions that they abut; not to have taken them from these regions. ${ }^{31}$ In this historiographic tradition of the corners' names, the outlook from the Kaaba is once again generative, once again organizational of the world. Islamic mappaemundi such as the $17^{\text {th }}$ century terrestrial one reproduced above in Fig. 3 and the cosmographic one reproduced below (Fig. 5), show the result of this organization.

Should this argument seem too abstract for some, too dependent on seemingly rarefied products of the creative imagination, in spite of the fact that mappaemundi are now largely understood as societally representative documents, then ${ }^{32}$ in its stead one can adduce an argument based on the geographically and historically widespread conceptualization of the Kaaba as the heart of humankind. Evidence for this conceptualization includes the popular, albeit disputed, prophetic saying (hadīth): »The heart is God's House.«33 The poet Rumi (d. I273) is likely alluding to this saying when he rhetorically addresses pilgrims heading for Mecca with the verse: »The heart is the intended Kaaba. Why do you bother with [the one of] clay? «34 Examples like this can be multiplied. ${ }^{55}$ From this conceptualization, the conclusion follows that, just as the corporeal, »intended « Kaaba gives life to the body, so the Kaaba of Mecca gives life to the world. 


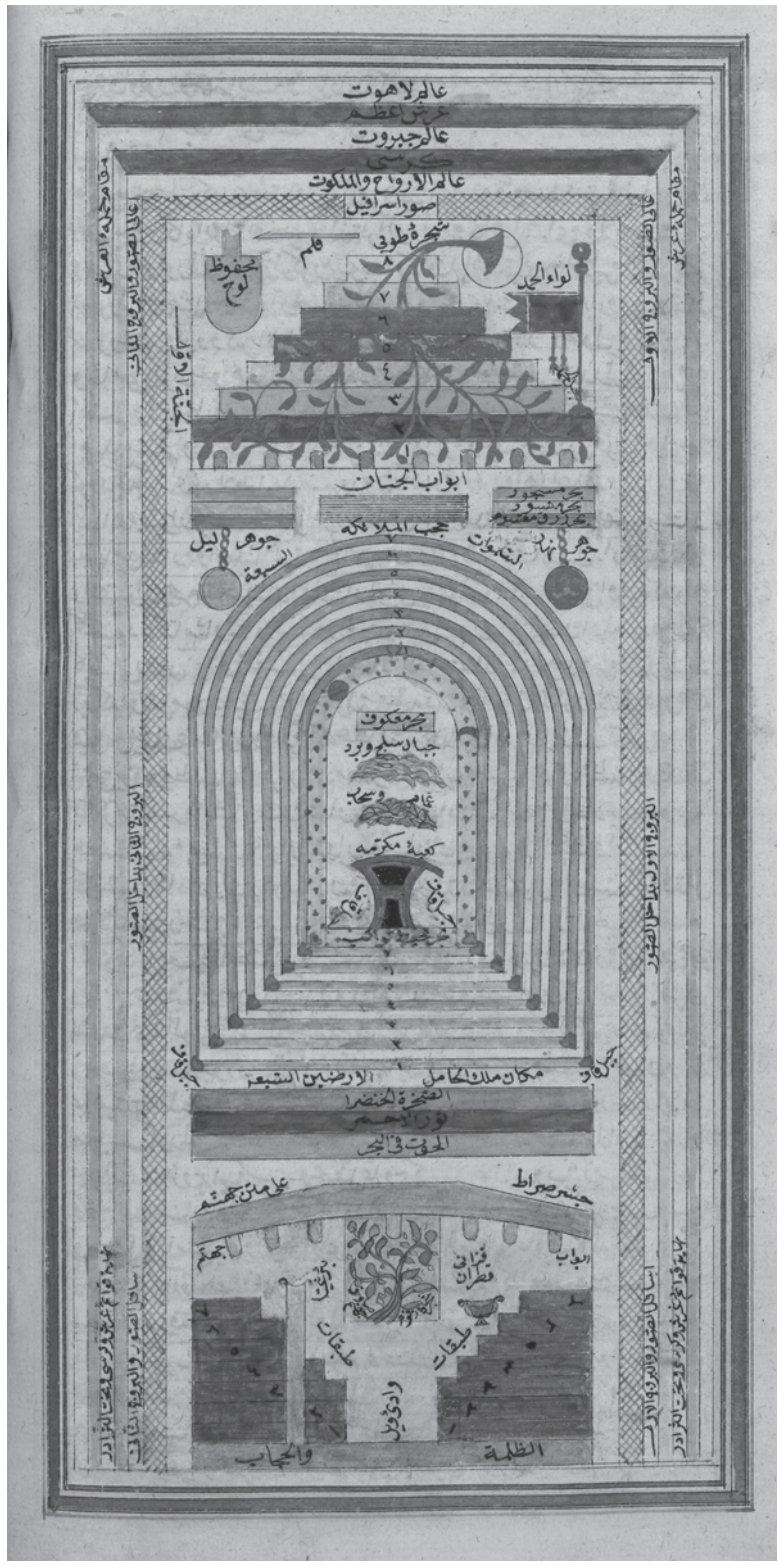

[FIG. 5]

Diagram of the Islamic cosmos with the Kaaba at the centre, from a copy of The Book of Gnosis by the Ottoman Sufi and scholar, İbrahim Hakk1 (d. 1780), dated I820. Gold, gouache, and ink on paper, $26 \times 14 \mathrm{~cm}$, The British Library. MS Or. 12964, fol. $23 \mathrm{v}$ 
In a fusion of these two conceptualizations of the Kaaba as world-generating and as the heart of humankind, a surveyed group of illiterate Moroccans drew maps of the world wherein Mecca was represented immediately adjacent to the villages or towns of their birth and/or work. The Moroccans explained that, »[Mecca $]$ is closest to the heart of Muslims. $\ll^{36}$

\section{Dirt, and a distinction between offense and insult}

Returning once more to the dictum made famous by Douglas, dirt is matter that has no location in a world-organizing outlook. Dirt in this dictum does not have to do with its place of occurrence, its locale or point of manifestation; the shoe on the dining table, for example. Dirt, rather, has to do with the generative, founding place whence this or that member of society says: »From here where I stand, this is how things are; this is how the world is. «77 In the foregoing analogy between dirt and offense, offense arises when something does not fit within such an outlook; the Kaaba perceived as being taken as a shop, for example. In contrast to insult, offense is also often unintentionally caused, which explains why the outcry over the "Kaaba of New York « was such a muted affair; it was mostly understood as an unintentional offense.

Without wishing to become mired in the academic literature regarding the two terms »offense« and »insult, « one can substantiate this distinction with the following banal, domestic scenario. The boss is invited for dinner at the employee's family home, but once seated at the table the host neglects to serve her, so accustomed is he to serving just his wife and children at this 
midweek dinner hour. Realizing his error, the employee quickly apologizes and passes the boss a plate of food. The offense that had begun to show on the boss's face disappears; it is clear to her that the momentary offense was unintentional. Suppose, however, that the employee had not subsequently proffered his boss a plate of food, but had instead handed her an empty plate along with a mocking smile, the meaning would be clear to all. He was insulting the boss. The offense was intentional..$^{8}$

If one now applies this trivial tableau to two recent world affairs considerably less trivial, namely, the Danish Muhammad cartoons affair of 2005 and the Charlie Hebdo affair of 2015, one can see the fit of the distinction the tableau draws between unintentional and intentional offense, or insult. In the earlier of these two affairs, the cartoonists were, according to an editor of the newspaper in which they appeared, aiming to test the boundaries of journalistic self-censorship with regard to Islamic topics. ${ }^{39}$ This test necessarily required them to make their cartoons as provocative as possible to Muslims; and in thus provoking Muslims, the cartoonists were effectively offending them intentionally. In the later, Charlie Hebdo affair, although the stated intentions of the cartoonists have not, to my knowledge, been authoritatively reported, I would argue that a cartoon such as the one of the Prophet Muhammad, naked and bent on his knees, his anus and pudenda exposed and swinging in the air, is unambiguous in intent: it is the boss's empty plate, one-thousandfold.

If the foregoing distinction between offense and insult holds, then it leads to the encouraging and surely unsurprising conclusion that Muslims are well able to discern the difference between what is an accidental offense and what is not, even if that judgment is not immediately reached but takes a little 
time, as in the Kaaba of New York affair. This ability will certainly be tried and tested in the future as more and more offensive and potentially insulting images inevitably circulate on the Internet.

The other unsurprising conclusion that follows is that Muslims distinguish between the various frames about the reproduction of what have, over time, become symbols of their religion, most especially between media- and religion-based frames. ${ }^{40}$ Regarding the latter, a photograph of the Kaaba on the sitting room wall of a Muslim's home in Cairo, say, is almost expected; for it helps to mark the home's sacrality (hurma)..$^{4 \mathrm{r}}$ As such, its placement there prompts no second glance. However, the same photograph mounted in a Copt's home in Cairo would likely elicit such a glance, for there it would be out of place. Additionally, until it was clear no offense or insult was meant by its placement there, the photograph would likely grate against the symbol of the Kaaba that is carried in the viewing Muslim's heart or soul. Momentarily or otherwise, the image would strike right at this heart or soul. ${ }^{2}$

\section{Conclusion}

The opportunity that the theme of this edited volume provides to reflect on a relatively low-key and thus little-known outcry concerning Apple Inc.'s perceived slight against the Kaaba has occasioned a number of findings, all of which have been drawn out in the preceding pages. Perhaps chief among these findings is the realization that the concept of place, at least as invoked by Mary Douglas, is not synonymous with space, but precedes it. Place opens up a world, making 
room for space, which can then be symbolized or represented (be it textually, artistically, legally, etc.) and thereby replicated, thus extending and preserving the world opened up. The specific, historical, complex nature of this space is little apparent to the eye; a copy of the Kaaba can, for example, be unproblematically set in Leeds or Hamburg, as we have seen. As such, many an urban setting - a medieval European city, say — can become incorporated into a Muslim's world as well as it can become incorporated into a non-Muslim's world, because nothing visible about its space renders it offensive. To misquote Archimedes: »Give me a place to stand and I shall see the world.«Europe can continue to share its cities even more.

1 The support of the European Research Council (Project no. 263308: »The here and the hereafter in Islamic traditions«) enabled the completion of this chapter.

2 http://www.memri.org/report/en/o/\%/\%/0/0/0/1901.htm (accessed on Dec. I6, 2014).

3 As cited, for example, in the anonymously authored article, »Muslim Radicals Take Bite Out of Apple, « in Metro, October 16 (2006), available online at: http:// metro.co.uk/2006/10/16/radicals-take-bite-out-of-apple280221/ (accessed on April 28, 2015). With thanks to Dr. Moya Carey for bringing this article to my attention.

4 On these four kaabas, see both Ibn al-Kalbī: The Book of Idols. Being a Translation from the Arabic of the Kitāb al-Aṣnām, trans. by Nabih Amin Faris, Princeton 1952, Pp.39-40; and Michael Kister: Mecca and the Tribes of Arabia. Some Notes on Their Relations, in Moshe Sharon (ed.): Studies in Islamic History and Civilization in Honour of Professor David Ayalon, Leiden 1986, pp. 33-57, here p. 44. Regarding one of these kabas, the one said to have been at Najran, see, additionally, Aziz al-Azmeh: The Emergence of Islam in Late Antiquity: Allāh and his Peo-ple, Cambridge 2014 , p. 222. As indicated in the main text, not all of these kaabas were necessarily imitations of the form of the Kaaba of Mecca.

5 Al-Bukhārī: Șahīḥ al-Bukhārī, ed. cAbd al-cAzīz b. cAbd Allāh b. Bāz, 8 vols., Beirut 1994, vol. 4, p. 280 (k. manāqib al-Anșār, bāb dhikr Jarīr b. 'Abd Allāh al-Bajallī, \#3822); trans. Aisha Bewley: The Sahih Collection of al-Bukhari, Chapter 66. Book of the Virtues of the Companions, $\#_{3} 6$ II (http://bewley.virtualave.net/ bukhari28.html\#companions (accessed on Dec. 16, 2014). 
6 Kister: Mecca and the Tribes of Arabia (see note 4), pp. 43-44.

7 Pace Nasser Rabbat, who considers that the Kaba "has rarely been copied in Islamic architectural history $[\ldots]$ « Idem: In the Beginning Was the House: On the Image of the Two Noble Sanctuaries of Islam, in Thresholds 25 (2002), pp. 56-59, here p. 58.

8 Muḥammad b. Aḥmad al-Muqaddasī: Kitāb aḥsan altaqāsīm fī ma rifat al-aqālīm, ed. M.J. de Goeje, 2nd ed., Leiden 1906, p. I22 (line 18); trans., idem: The Best Divisions for Knowledge of the Regions. A Translation of Aḥsan al-Taqāsīm fī Ma rifat al-Aqālīm, trans. by Basil Anthony Collins, Reading 200I, P. Io2. One might be right to see in this report an ideologically motivated attempt to discredit a caliph who had so unsparingly forced upon his people the theological tenets of the Mu'tazilites.

9 Ibid., p. 199 (line ro); trans., p. 168.

${ }^{10}$ Ḥamd Allāh Mustawfī Qazwīnī: The Geographical Part of the Nuzhat al-qulub, composed by Ḥamd-Allāh Mustawfī of Qazwīn, in 740 ( $1340 \mathrm{AD})$, ed. and trans. by Guy Le Strange, 2 vols., Leiden 1915-1919, vol. 2, p. 96.

11 Zayn al-Dīn 'Umar b. al-Muẓaffar b. al-Wardī: Ta'rīkh Ibn al-Wardī, 2 vols., Najaf 1969, vol. 2, P.I32, as cited in 'Ali' b. Abi'-Bakr al-Harawī: A Lonely Wayfarer's Guide to Pilgrimage. 'Ali b. Abi-Bakr al-Harawī's Kita b al-Ishārāt ila-ma rifat al-ziyārāt, trans. by Josef W. Meri, New Jersey 2004 , p. xxiv.

12 Copies of the Kaaba made during the last fifty years include one of the largest mosques in the world, the Baitul Mukarram mosque in Dhaka, Bangladesh, completed in 1968, whose prayer hall is modeled on the Kaaba. Possibly the most recent copy of the Ka aba is the one that was put on display by a religiously conservative municipality of Istanbul for the week of the Prophet Muhammad's birthday celebrations of 2015 . This copy was part of a temporary, com memorative installation, whose nearest equivalent might be said to be a Christmas nativity installation See, e.g., the anonymously authored article, Turkey: >Model Meccar Opens in Istanbul District, BBC News website, April 22, 2015 (http://www.bbc.co.uk/news/ blogs-news-from-elsewhere-32412530 (accessed on April 29, 2015). This copy, it is true, did provoke an outcry and had to be removed, but that was due to a self-proclaimed performance artist in pilgrimage garb (iḥrām) trying to circumambulate the model as if it were the real thing. With thanks to Dr. Moya Carey for bringing this entire story to my attention and to Professor Scott Redford for discussing it with me.

13 Gregor Schneider et al.: Cubes: Art in the Age of Global Terrorism, Milan 2006, pp. 39-42; and R. Jay Magill Jr.: A Cube, Like Mecca's, Becomes a Pilgrim, in The New York Times, April 15, 2007, available online at: http://www. nytimes.com/2007/04/rs/arts/design/15magi.html?pagewanted $=a 11 \& \_r=0 \quad$ (accessed on April 17, 2015).

${ }^{14}$ Schneider: Cubes (see note 13), pp. 24-29.

15 Ibid., pp. 18, 27-28. For at least the Berlin Biennale, this ban was upheld in spite of a statement from the Central Council of Muslims in Germany supporting the exhibition of the Cube. In Hamburg, where the Cube was finally exhibited, Muslims have apparently welcomed its display. Magill: A Cube (see note I3). 
${ }^{16}$ Other explanations certainly exist, including economic ones and political, post-9/II ones; what follows is not intended to be exclusive.

${ }^{17}$ Mary Douglas: Purity and Danger. An Analysis of the Concepts of Pollution and Taboo, London 1966, p. 36 .

${ }^{18}$ Ibid., pp. 35-36.

19 Ameena Mughal: Hajj items. Souvenirs from Mecca pilgrims, in Secret Lives of Objects. Go Behind the Scenes at Leeds Museum and Galleries weblog, I7.05.20I2 http://tinyurl.com/z7693mq (accessed on Dec. I4, 2016).

${ }^{20}$ Strictly speaking - in order to ensure the comparison is between like and like - because the outcry over the »Kaaba of New York« resulted mostly from individuals seeing on the Internet uploaded photographs of this building, one should be asking whether the uploaded photograph of the »Kaaba of Leeds " provoked outcry. To the best of my knowledge, the answer to that is: no.

${ }^{21}$ One might additionally refer to the Saudi government's ongoing, monumental building campaign just beyond Mecca's Sacred Mosque. The Kaaba, which the walls of this mosque surround, is utterly dwarfed by the new buildings and skyscrapers there. To all intents and purposes, this new architectural setting also falls under the classification of modern Western; but relatively speaking, only a few Muslims appear to have been offended by the view of the Kaaba within it. For a prominent example of such an offended Muslim, see Ziauddin Sardur: The Destruction of Mecca, in The New York Times, September I4, 2014 , available online at: http:/www.nytimes.com/2014/ro/or/opinion/the-destruction-of-mecca.html? smprod=nytcore-ipad\&smid=nytcore-ipad-share\&_r=o (accessed on April 2I, 2015). With thanks to Dr. John Gibson for bringing this point to my attention.

22 Jonathan Z. Smith: The Influence of Symbols Upon Social Change: A Place on Which to Stand, in Worship 44/8 (1970), Pp. 457-74, here p. 469; italics as marked in the original.

${ }^{23}$ Martin Heidegger: The Origin of the Work of Art, in idem: Poetry, Language, Thought, trans. by Albert Hofstadter, New York 1971, p. 43.

${ }^{24}$ Mark Wigley: The Architecture of Deconstruction. Derrida's Haunt, Cambridge/Mass. 1993, p. 6r.

${ }^{25}$ As cited in translation in Arent Jan Wensinck: The Ideas of the Western Semites Concerning the Navel of the Earth, in Verhandelingen der Koninklijke Akademie van Wetenschapen te Amsterdam, Afdeeling Letterkunde, n.s., I7/I (1916), pp. I-65, here p. I8.

${ }^{26}$ Ibid. For a discussion of these reports as they pertain to the Kaaba, see Simon O'Meara: Orientations in Space and Vision, Edinburgh 2017 , Chapter 2.

${ }^{27}$ See e.g. David A. King: World-Maps for Finding the Direction and Distance of Mecca. Innovation and Tradition in Islamic Science, Leiden 1999.

${ }^{28}$ Petra Schmidl / Mónica Herrera-Casais: The Earliest Known Schemes of Islamic Sacred Geography, in Anna Akasoy / Wim Raven (eds.): Islamic Thought in the Middle Ages. Studies in Text, Transmission and Translation, in Honour of Hans Daiber, Leiden 2008 , pp. $275-99$, here p. 277 .

${ }^{29}$ Ibid., 280. 
${ }^{30}$ Ibid., 277.

31 See e.g. Yossef Rapoport / Emilie Savage-Smith (eds.): An Eleventh-Century Egyptian Guide to the Universe. The Book of Curiosities, Leiden 2014, p. 436 (Arabic text: p. 156).

${ }^{32}$ For example, with reference to mappaemundi of medievalChristianity, it is said that they" provide a glimpse into the socially-constructed symbolic world of medieval persons, their mental map, their spatial reality, their universe of discourse.« Jon R. Stone: The Medieval Mappaemundi. Toward an Archaeology of Sacred Cartography, in Religion 23 (1993), pp. 197-216, here p. 200 . More recently Maria Kupfer has written: "[Mappamundi]-making involved more than the selective appropriation and collation of geographic information. Both the task of inscription on a particular support and the circumstances of display in a given context made demands on the cartographic figure itself, conceived and manipulated in relation to codicological structures, architectural spaces, or quasi-stationary installations. The image of the world, conditioned by the material constraints of the mappamundi, never stood alone.«Idem: Mappaemundi: Image, Artefact, Social Practice, in P.D.A. Harvey (ed.): The Hereford World Map: Medieval World Maps and their Context, London 2006 , pp. 253-67, here p. 254.

33 "Al-qalb Bayt Allāh.«On its dismissal as inauthentic, see e.g. Aḥmad Ibn Taymiyya: Majmūat al-fatāwā li-shaykh al-Islām Taqī al-Dīn Aḥmad Ibn Taymiyya al-Ḥarrān̄̄, ed. 'Āmir al-Jazzār and Anwār al-Bāz, 37 vols., Alexandria 1997, vol. I8, p. 7I.

34 »Dil-ast Ka‘ba-yi ma'nī, tu gil che pindārī.«Jalāl al-Dīn Rūmī, Kullīyāt-i Shams yā Dīwān-i kabīr, mushtamil bar qașā’id wa ghazalīyāt wa muqațta āte-i fārsīwa 'arabī wa tarjī̄āt wa mulamma'āt, az guftār-i mawlānā Jalāl al-Dīn Muḥammad mashhūr bi-Mawlawī, Badī alZamānFurūzānfar(ed.), 7vols., Tehran 1958, vol. 6, p. 298 (line 33,104$)$.

${ }^{35}$ See O’Meara: Kaaba (see note 26), Ch. 3.

${ }^{36}$ Mohamed Boughali: La représentation de l'espace chez le marocain illettré: mythes et tradition orale, Paris 1974, p.189.

${ }^{37}$ In the confessional parlance typical of contemporary celebrity culture, today one might say, $\gg \mathrm{I}$ was in a bad place at the time, "where place is not a burning building but the emotional state generating the confessor's outlook.

${ }^{38}$ Another, less labored example is as follows. A I2-yearold schoolgirl draws a naked figure and then drops it on the classroom floor; the teacher later finds it and is momentarily offended by the displayed pudenda. Another schoolgirl draws the same figure but adds the teacher's name below it; the teacher finds it and feels insulted.

39 Flemming Rose: Muhammedsansigt, in Jyllands-Posten, September 29, 2005, available online at: http://jyllandsposten.dk/indland/ECE4769352/muhammeds-ansigt/ (accessed on April I6, 2015).

${ }^{40} \mathrm{On}$ the notion of the Kaaba as a symbol, see Jan Hjärpe: The Symbol of the Centre and its Religious Function in Islam, in Haralds Biezais (ed.): Religious Symbols and Their Functions. Based on Papers read at the Symposium on Religious Symbols and their Functions held at Abo on the 28th-3oth of August 1978, Stockholm 1979, pp. 30-40, esp. p. 31.

${ }^{41}$ See e.g. Juan Eduardo Campo: The Other Sides of Para- 
dise: Explorations into the Religious Meanings of Domestic Space in Islam, Columbia 1991, p. I25.

${ }^{42}$ I owe the notion of the power of images to be able to strike in this way to Jojada Verrips. 